\title{
Gauging the Effect of Performance Management and Technology Based Human Resource Management on Employee Retention: The Perspective of Academics in Higher Educational Institutions in Sokoto State Nigeria
}

\author{
Abubakar Allumi Nura ${ }^{1} \&$ Nor Hasni Osman ${ }^{2}$ \\ ${ }^{1}$ Department of Technology and Operations Management, Universiti Utara Malaysia, Malaysia \\ ${ }^{2}$ Department of Technology and Operations Management, School of Technology Management and Logistics, \\ Malaysia
}

Correspondence: Abubakar Allumi Nura, Department of Technology and Operations Management, Universiti Utara Malaysia, Malaysia. E-mail: nallumi@yahoo.com

Received: July 15, 2013 Accepted: August 29, 2013 Online Published: October 29, 2013

doi:10.5539/ass.v9n15p295 URL: http://dx.doi.org/ass.v9n15p295

\begin{abstract}
For decades ago precisely during the late 70's personnel management and administration was chosen to be the desirable for office practices as far as designing and maintaining payroll as well as keeping employee records is concerned. Normally this information is kept in a data base and retrieved on demand. This was however to be replaced by the sophisticated technology based human resource management (E-HRM) that emerges to help modernize, update and re structure core human resource management (HRM) practices, reduce costs, and perk up efficiency. This study investigates the connection between performance management system, technology based human resource management (E-HRM) and employee retention; among academics in higher educational institutions in Nigeria. The findings revealed that the successes and achievements of technology based HRM in companies are not beyond the reach of higher educational institutions.
\end{abstract}

Keywords: performance management system, E-HRM, employee retention

\section{Introduction}

There are numerous interpretations of the concept of technology based HRM (E-HRM) by several scholars in the academia, the most popular works in the field of E-HRM today are those of Strohmeier (2009), Ruel et al. (2007), Bondarouk (2011), Sareen (2012), Lepak et al. (2007), Guiderdoni (2009), Imperatori and De Marco (2009), Marler, (2009), Pawlowski and Richter (2010) and Stone (2009). Perhaps the most cited definitions of E-HRM are those which were put forward by Strohmeier (2009) and Strohmeier and Kabst, (2009) i.e. E-HRM was clearly defined as a way of executing and implementing HRM practices, policies and strategies via conscious support of web based technology. This definition is further enhanced in the argument by Strohmeier (2009) who pointed out that E-HRM depicts an information technology application to support the performance of HRM practices by both individual and the group or collective actors in an organization. In a similar dimension, Ruel et al. (2004) postulate that E-HRM is a way of discharging responsibility which revised for the better, way and manner HRM strategies, policies and practices were undertaken. E-HRM has gained popularity and since becomes part of academic focus (Stanton \& Coovert, 2004; Townsend \& Bennett, 2003; Viswesvaran, 2003).

\subsection{Issue}

Academics in higher educational institutions in Nigeria have been accused by many of being always un satisfied in their jobs and obsessed to be in the comfort zone against all odds, very tough, controversial and greedy that even after their demands were met, their commitment cannot be guaranteed as they tend leave the higher educational institutions at will. This is way too many. The academia is more of a status based than it is of money based that is the researchers' opinion anyways. The critics should know that still some higher educational institutions in Nigeria are battling with ineffective traditional human resource management practice which makes the whole system exposed and vulnerable. For instance recruitment is done in house thereby limiting the scope from being effective and competitive, staff development made subjective to mention just a few, hence the system 
became weary and unprepared for unannounced employee separation. Academics leave higher educational institutions due to inability to effectively manage their performances, lack of regard for their career development among others. This paper intends to examine how technology based human resource management relates with employee retention and performance management in higher educational institutions in Nigeria.

\section{Related Literature}

\subsection{The Role of E-HRM in Ensuring Effective Performance Management System}

There are several researches that explained how E-HRM enhances organizational performances and the management of those performances as well. For instance Lengnick-Hall \& Moritz, (2003) pointed out that E-HRM offers a portal that allows managers, employees, and HR professionals to ably examine, extract, and revise key information for effective performance management in an organization. If at all effective Performance Management System can be evaluated using the indices provided in Ad Esse (2006) from the perspectives of organizational objective, individual objective, performance development, performance measurement and job performance, then the use of E-HRM to streamline the processes involved in getting the right caliber of employees to man positions in an organization, sorting and contacting the candidates (Galanaki, 2002),can accomplish magnificent cost effectiveness and time saving (Panayotopoulou et al., 2007).

Development been an important factor for Performance Management in an organization has today become one of the widely discussed edges of E-HRM as having the most potentials in terms of cost effectiveness (Akrani, 2009). More so, the concept of e-learning and simulation as learning tools are continuously becoming incorporated into technology based human capital development in organizations. These learning simulations as Schramm (2008) established, aid and lessened the need to use the actual submission and save costs. In the aspect of talent management (Cascio, 2006), employee maintenance (Delcampo, 2011), compensation (Ngai \& Wat, 2006) corporate communication (Holincheck et al., 2007), a drastic paradigm shift has been witnessed from a traditional labor intensive, HRM to a sophisticated technology intensive E-HRM that assures a robust Performance Management (Florkowski \& Olivas-Luja'n, 2006).

In some researches it was suggested that in various organizations radical changes have been made especially in the areas of work re distribution i.e. some activities that were before reserved for HR managers are efficiently performed by employees (Ruel et al., 2004; Ruta, 2005), employees are availed with the necessary opportunity to pursue and develop their career and manage their personal files (Roehling et al., 2005) and process training requirements themselves that were before distant from them. Bondarouk and Ruel, (2010) reported that the roles of E-HRM in attaining a robust Performance Management System in an organization have been summarized into six groups by distinct scholars, thus:

1) E-HRM generates HRM metrics to support strategic decision making which is key to Performance Management System in an organization (Bondarouk \& Ruël, 2009; Hendrikson, 2003; Hussain et al., 2007; Lawler et al., 2004; Lengnick-Hall \& Moritz, 2003).

2) E-HRM ushers in the automation of routine of HR tasks and practices by replacing the filing cabinets (Brown, 2002; Martinsons, 1994; Parry et al., 2007).

3) E-HRM ensures branding and re branding of organizations (Lawler \& Mohrman, 2003; Martin et al., 2008).

4) E-HRM relieves HR staff from administrative burdens and allowing them to focus on strategic Performance Management System (Lepak \& Snell, 1998; Martin et al., 2008; Ruel et al., 2004; Shrivastava \& Shaw, 2004).

5) E-HRM improves talent management through e-selection, self-assessment and e-performance management (Martin et al., 2008).

6) E-HRM transforms HR professionals from administrative paper handlers to strategic partners (Bell et al., 2006; Broderick \& Boudreau, 1992; Keegan \& Francis, 2008; Voermans \& Veldhoven, 2007).

\subsection{Measuring E-HRM}

In an attempt to provide an indices to measure E-HRM effectiveness this study will adopt a framework for measuring E-HRM provided by Maatman (2006). Thus:

The framework highlighted three main factors that jointly evaluate the effectiveness of E-HRM these factors are E-HRM goals; the use of E-HRM and the impact of E-HRM on the effectiveness and efficiency of the HR system. These factors are explained in detail below. 


\subsection{E-HRM Goals}

Different organizations are with different goals and objectives, same is with E-HRM goals. Nevertheless, some major issues raised by Maatman (2006) are mainly to augment and supplement the traditional HR practices for better outcome and lesser cost. For example for recruitment aspect Cober et al. (2004) argued that E-HRM will ease the search of qualified personnel by enabling organizations use their own websites better and saving time as well. It was also made clear in the argument put forward by Huselid (2004) who believed for organizations who intend to relieve their HR professional of the burden or tasking administrative responsibilities, the choice of E-HRM would be the answer they seek. In a related perspective, E-HRM has been linked to better financial discipline and performance in organizations and improved service delivery and service quality (Lengnick-Hall \& Moritz, 2003).

Even though there exists a line of demarcation between public and private organizations in terms of goals, motives and scope, their goals of implementing E-HRM are not very much different (Foust, 2007; Ruel et al., 2004). Consequent upon this assertion, Ruel et al. (2004) identified four main issues as the major goals of implanting E-HRM in organizations, these are:

1) Cost reduction/ efficiency gains

2) Client service improvement

3) Improving strategic orientation

4) Allowing integration of HR functions

\subsection{The Use of E-HRM}

Maatman (2006) pointed out three main points that explains the use or rather actual use of E-HRM in an organization these are: the E-HRM activities; the type of technology support for the E-HRM and the extent of user acceptance of the E-HRM technology.

It is expected that when E-HRM has been implemented in an organization, there has to be a lot of redistribution of responsibilities, i.e. who does what when and how. In some cases E-HRM is mainly situated to capture compensation issues being the most all-encompassing form of bureaucracy in an organization (Noe et al., 2008). Lepak et al. (2005) postulated that way and manner technology is used in an organization determines its impact upon the user. Besides, the implementation of HR activities through the support of E-HRM can occur in different forms i.e. it could be data collection, storing and retrieval. Again, user acceptance on the technology of E-HRM also matters in an organization (Venkatesh et al., 2003). Similarly, it has been argued that there is a link between user acceptance of technology and the success of the technology adopted.

\subsection{The Impact of E-HRM on the Effectiveness of the HRM System}

This impact According to Maatman (2006) can be evaluated from two different angles:

\section{1) E-HRM technology impact on the HRM performance}

\section{2) E-HRM technology impact on the job of the HR professional}

There are various arguments on the effectiveness of HR system and with different concerns. Some studies singled out one HR activity and focus on its in-depth analysis (Sun \& Cahan, 2012) while others attempted an overall analysis of the HR system (Armstrong, 2008). Lepak et al. (2005) pointed out that it is imperative to consider three levels in analyzing the effectiveness of HR system, the levels according to Lepak et al. (2005) comprise of HR philosophy, HR policies and programs and HR practices and processes, are interwoven. These levels of analysis are very critical and key to the understanding of the use and effectiveness of HR system in part and as a whole (Lepak et al., 2005).

\subsection{E-HRM as the Mediator}

This paper uses E-HRM as a mediating variable in the relationship between employee retention and performance management system in higher educational institutions in Nigeria. Going by the elaborations of Baron and Kenny (1986) and Judd and Kenny (1981), the ordeal for using a mediator variable is to examine the relationship between the dependent and independent variables, the relationship between mediator and the dependent variables as well as the relationship between mediator and independent variables. They further added that in an event of total mediation, the relationship between independent and dependent variables should be reduced after checking or controlling the relationship between the mediator and dependent variables. If all the aforementioned steps are met, then the data are dependable with the hypothesis that there is a complete mediation, but if the first three were realized and the fourth is not met, then it is considered that there is partial mediation (Kenny, 2012). 
E-HRM has been used as an intervening variable in the relationship between internal customers and external suppliers which acted as a catalyst in ensuring an increased institutional visualization of procurement processes. Similarly, Brockbank and Ulrich (2003) proffered in their model that there is need for HR professionals to be able to pull technology for HR practices and use e-HR/web based channels to effectively deliver services to their clients. Joseph and Kitlan (2008) pointed out in their research that E-HRM has been proven to be a critical mediator in the relationship between government and its constituents as far as the execution of governmental transactions via E-HRM channels are concerned. In a research by Loijen (2011) it has as well been shown that E-HRM has been used as a mediator in the relationship between success enablers and value creation. Value creation takes precedence according to porter (1985) the moment organizations devise or are devising new ways of undertaking their activities. And as Loijen (2011) argued E-HRM is a new invented way of implementing HR functions and practices in an organization and as a result of which HR processes become standardized. Loijer (2011) further argued that if successfully adopted, E-HRM brings with it outstanding benefits to both the employees and the organization.

\subsection{Employee Retention and Performance Management}

Employee retention has been interpreted as a multifarious notion which has no universally acceptable connotation but it is believed to mean a responsibility to go on with a particular organization as an employee (Zineldin, 2000). Others consider it as customer liking, recognition, obligation, confidence, and willingness to suggest, and repurchase intentions (Stauss et al., 2001). From another dimension, it has been argued that employees are strategically changing working places to be able to get their needs satisfied and guarantee security of tenure. Logan (2000) further stressed that instead of helplessly allowing employee turnover become more prominent, organizations attain success if they provide development programs to ably retain workers.

It has also been buttressed that the efforts put in place by organizations to ensuring quality condition of service, influence to greater extent employee retention (Walker, 2001). In a related fashion, Moses (2000) particularly pointed out that it is the strategy involved in the implementation of human resource management practices as well as effective performance management that jointly check and reduce turnover to the barest minimum. No wonder it is often argued that employees leave their jobs if their performances are not properly managed coupled with availability of alternative vacant positions in other organizations, even though Hytter (2007) emphasized that employee turnover and retention are dependent upon attitudes of employees towards their jobs.

In quite a number of empirical justifications, such as Lockwood's, (2006) Steel et al., (2002) Verheijen and Dewulf (2004), it has been established that employee retention and worker satisfaction are significantly correlated which clearly signifies that satisfied employees are those who are happy with their jobs and are more dedicated to doing a good job.

\section{Methodology}

This paper adopts a quantitative method of analysis such that the views of respondents are analyzed using SPSS.

\subsection{Population and Sample of the Study}

All academic members of staff of higher educational institutions in Sokoto state comprise the targeted population. The paper however conveniently selected 300 respondents out of which, only 196 provided the information related to the topic selected, and the analysis however is based on the 196 respondents.

\subsection{Research Design}

This study focused mainly on technology based human resource management (E-HRM), employee retention and performance management system in higher educational institutions in Nigeria. The temperament of this study is more of a fact finding thus, it pursues descriptive study design as its map of action.

\subsection{Instrument}

A single instrument was used for data collection which was designed on a 4-point Likert scales to assess the various variables. The study did content and construct analysis by making use of wide-ranging literature and formerly validated constructs. It institutes further the incorporation of the representativeness of the items in the questionnaire for adequate data collection.

\subsection{Validity and Reliability}

The final data inputs were typed in into a statistical package (SPSS) various statistical analyses and the Cronbach alpha determine the reliability of each of the constructs. Descriptive analysis was undertaken, and the KMO and commonality were also determined. 
Table 1. Descriptive statistics of variables

\begin{tabular}{lllll}
\hline Variable & No of Items & KMO & Cronbach Alpha & Commonality \\
\hline PMS & 12 & .71 & .846 & .877 \\
Employee retention & 14 & .65 & .880 & .973 \\
Technology based HRM & 16 & .66 & .896 & .760 \\
Total items & $\mathbf{4 2}$ & & & \\
\hline
\end{tabular}

The three variables in table 1 above show Cronbach alpha values of 0.80 and above indicating complete reliability since 0.75 is the generally acceptable value (Nunally, 1970). KMO and communality of the measures were also confirmed. Cronbach alpha obtained for the variables are as follows: .846 for performance management system (PMS) with a commonality value of .877 and KMO value of $0.71, .880$ for employee retention (ER) with a commonality value of .973 and $\mathrm{KMO}$ value of $0.65, .896$ for technology based human resource management practice (E-HRM) with a commonality value of .760 and KMO value of 0.66.

\subsection{Implication of the Responses Given by the Respondents on Each of the Variable Items}

Table 2. Implication of the responses on performance management system (PMS)

\begin{tabular}{lllll}
\hline Scales & & Frequency & Percent & Cumulative Percent \\
\hline SD & 1 & 7 & 3.6 & 3.6 \\
D & 2 & 7 & 3.6 & 7.1 \\
A & 3 & 58 & 29.6 & 36.7 \\
SA & 4 & 124 & 63.3 & 100.0 \\
& Total & 196 & 100.0 & \\
\hline
\end{tabular}

Table 2 above indicates that out of the 196 returned questionnaires, 14 respondents opted for the first two options SD (strongly disagree) and D (disagree) thus occupied 3.6\% each respectively. Similarly, 58 responses went for the third option A (agree) they represent $29.6 \%$ while the remaining 124 responses chose the fourth option SA (strongly agree) and tremendously represent $63.3 \%$.

Table 3. Implication of the responses on employee retention (ER)

\begin{tabular}{lllll}
\hline & & Frequency & Percent & Cumulative Percent \\
\hline SD & 1 & 6 & 3.1 & 3.1 \\
D & 2 & 18 & 9.2 & 12.2 \\
A & 3 & 56 & 28.6 & 40.8 \\
SA & 4 & 116 & 59.2 & 100.0 \\
& Total & 196 & 100.0 & \\
\hline
\end{tabular}

Table 3 above shows that $3.1 \%$ representing the views of 6 respondents strongly disagreed with the questions on employee retention, 9.2\% selected the second option D (disagree), they represent the views of 18 respondents, $28.6 \%$ opted for the third option A (agree) representing the opinions of 56 respondents and $59.2 \%$ chose the fourth option SA (strongly agree) this perhaps represent the dominating figure of 116 respondents. 
Table 4. Implication of the responses on technology based HRM (E-HRM)

\begin{tabular}{lllll}
\hline & & Frequency & Percent & Cumulative Percent \\
\hline SD & 1 & 2 & 1.0 & 1.0 \\
D & 2 & 7 & 3.6 & 4.6 \\
A & 3 & 59 & 30.1 & 34.7 \\
SA & 4 & 128 & 65.3 & 100.0 \\
& Total & 196 & 100.0 & \\
\hline
\end{tabular}

Table 4 above shows that 2 responses representing $1 \%$ of the views of respondents disagreed strongly with the questions on E-HRM, 7 respondents whose views represents 3.6\% chose the second option D (disagree) and 128 responses dominating the larger percentage of $65.3 \%$ believe the fourth option SA (strongly agree) is the best answer.

Discriminant Validity Construct

Table 5. Average variance extracted (AVE)

\begin{tabular}{llll}
\hline Variable & 1 & 2 & 3 \\
\hline PMS & 1 & & \\
Employee retention & .977 & 1.00 & 1.00 \\
Technology Based HRM & .961 & .953 & \\
\hline
\end{tabular}

Table 6. Correlation and correlation square matrix among variables

\begin{tabular}{llll}
\hline Variable & 1 & 2 & 3 \\
\hline PMS & 1 & & \\
Employee retention & $.812(.644)$ & 1.00 & 1.00 \\
Technology Based HRM & $.737(.655)$ & $.713(.638)$ & \\
\hline
\end{tabular}

\section{Discussions}

The implication of responses on items of the variables indicates that majority of the respondents agreed with the questions which are evidently clear in their choices of the higher options 3 (Agree) and 4 (Strongly agree). In all the three variables, respondent's choices of the higher options 3 (Agree) and 4 (Strongly agree) tremendously dominated i.e. in the responses on performance management system, it was $92.8 \%$ against $7.2 \%$ in favor of higher options 3 (Agree) and 4 (Strongly agree); for responses on employee retention, 3 (Agree) and 4 (Strongly agree) dominated with $87.7 \%$ as against $12.3 \%$ for the lower options 1 (Strongly Disagree) and 2 (Disagree). It was also seen in the responses for technology based HRM that higher options 3 (Agree) and 4 (Strongly agree) dominated with $95.4 \%$ against $4.6 \%$ of the lower options 1 (Strongly Disagree) and 2 (Disagree). This implies that the items presented in this study appropriately measured the variables and further confirmed the results in the validity and reliability of the variable items earlier in table 1 .

Since the Average Variance Extracted (AVE) as proposed by Fornell and Larker (1981) as a determinant of the shared variation in a Latent Variable should be more than the correlation squared of two constructs to be able to support Discriminant validity. Since this assertion turns out to be true, as shown in tables 4 and 5, then it confirms that there is no multi-co linearity thus the variables can be considered distinct and unique.

The results of this study imply that there is a significant correlation between employee retention and performance management system in every day administrative processes in higher educational institutions. This perhaps coincides with researches of Tan and Teo (2000) and Abukhazam and Lee (2010).

Again, technology based HRM and its expediency have been proven to have a significant relationship with employee retention because technology based HRM holds the nature of reducing the time, energy and cost incurred for the human resource processes occupied in the academic administrative activities. Various scholars 
such as Lengnick-Hall \& Moritz, (2003); Malhotra (2005) believe that the use of information and communication technology for human resource practices especially development and welfare will make strategic decision-making effective and efficient as well as less incidence of conflicts between employer and employee thus, invariably checkmates their intent to leave.

Similarly, technology based HRM is significantly related to performance management system among academics in higher educational institutions in Sokoto state. This is perhaps so because the application of HR technology in the educational institutions guarantees a desired output behavior of staff i.e. less complaints and conflicts are reduced to barest minimum. This is perhaps in line with the views of Nura et al., (2012) and Maatman (2006).

\section{Policy Implication}

It could be understood here that the literature review and the findings of the present research further establish that the successes recorded of technology based HRM particularly in companies are not beyond reach in educational settings. No wonder, Scholarly findings assert that technology based HRM checkmates the difficulties related to employee turnover irrespective of the organization they work for. A supportive effort from the federal government in Nigeria and Ministries of Education (both Federal and State) towards ensuring harmony and better outcome and productivity in higher educational institutions is considered necessary by providing the needed facilities.

\section{References}

Abukhzam, M., \& Lee, A. (2010). Workforce Attitude on Technology Adoption and Diffusion School of the Built Environment. University of Salford, Maxwell Building, the Crescent, Salford, M5 4WT, UK.

Ad Esse Consulting Limited. (2006, May 18). Measuring Performance Management. Retrieved December 16, 2011, from http://www.ad-esse.com

Akrani, G. (2009, December 27). Human Resource Management and Development. Retrieved March 16, 2011, from http://www.kalyan-city.blog.com

Armstrong, M. (2008). Strategic Human Resource Management: A Guide to Action (4th ed.).

Baron, R., \& Kenny, D. (1986). The moderator-mediator variable distinction in social psychological research: conceptual, strategic, and statistical considerations. Journal of Personality and Social Psychology, 51, 1173-1182. http://dx.doi.org/10.1037/0022-3514.51.6.1173

Bell, B., Lee, S., \& Yeung, S. (2006). The impact of e-HR on professional competence in HRM: Implications for the development of HR professionals. Human Resource Management, 45(3), 295-308. http://dx.doi.org/10.1002/hrm.20113

Bondarouk, T. (2011). E-HRM. Enschede: University of Twente.

Bondarouk, T., \& Ruël, H. (2009). Electronic Human Resource Management: challenges in the digital era. The International Journal of Human Resource Management, 20(3), 505-514. http://dx.doi.org/10.1080/09585190802707235

Brockbank, W., \& Ulrich, D. (2003). Competencies for the New HR: Society for Human Resource Management. University of Michigan Business School, United States: Global Consulting Alliance.

Broderick, R., \& Boudreau, J. (1992). The evolution of computer use in human resource management: interviews with ten leaders. Human Resource Management, 30(4), 485-508. http://dx.doi.org/10.1002/hrm.3930300405

Brown, D. (2002). EHR-Victim of Unrealistic Expectations. Canadian HR Reporter, 15(16), 1-6.

Cascio, W. F. (2006). Managing Human Resources: productivity, Quality of Work Life, Profits (7th ed.). New York: McGraw-Hill companies, Inc.

Cober, R., Brown, D., Keeping, L., \& Levy, P. (2004). Recrutiment on the Net: How Do Organizational Web Sites Characteristics Influence Applicant Attraction? Journal of Management, 30(5), 23.

Delcampo, R. G. (2011). Human Resource Management Demystified: Hard stuff made easy. USA: McGraw-Hill Companies Inc.

Florkowski, G., \& Olivas-Lujan, M. (2006). The diffusion of human resource information-technology innovations in US and non-US firms. Personnel Review, 35(6), 684-710. http://dx.doi.org/10.1108/00483480610702737

Fornell, C., \& David, F. L. (1981). Evaluating Structural Equation Models with Unobservable Variables and 
Measurement Error. Journal of Marketing Research, 18, 39-50. http://dx.doi.org/10.2307/3151312

Foust, D. (2007). How Technology Delivers for UPS. New York: BusinessWeek.

Galanaki, E. (2002). The decision to recruit online: a descriptive study. Career Development International, 7(4), 243-251. http://dx.doi.org/10.1108/13620430210431325

Guiderdoni-Jourdain, K. (2009). The enrichment of the HR Intranet linked to the regulation processes between HR actors. In T. Bondarouk, H. Ruel, K. Guiderdoni-Jourdain \& E. Oiry (Eds.), Handbook of Research on e-Transformation and Human Resources Management Technologies: Organizational Outcomes and Challenges. New York: Hershey. http://dx.doi.org/10.4018/978-1-60566-304-3.ch017

Hendrickson, A. (2003). Human resource information systems: Backbone technology for contemporary human resources. Journal of Labor Research, 24(3), 381-394. http://dx.doi.org/10.1007/s12122-003-1002-5

Huselid, M. (2004). Editor's Note: Special Issue on e-HR: The Intersection of Information Technology and Human Resource Management. Human Resource Management, 43(2\&3), 119.

Hussain, Z., Wallace, J., \& Cornelius, N. (2007). The use and impact of human resource information systems on human resource management professionals. Information \& Management, 44(1), 74-89. http://dx.doi.org/10.1016/j.im.2006.10.006

Hytter, A. (2007). Retention strategies in France and Sweden. The Irish Journal of Management, 28(1), 59-79.

Imperatori, B., \& De Marco, M. (2009). E-work \& labour processes transformation. In T. Bondarouk, H. Ruel, K. Guiderdoni-Jourdain \& E. Oiry (Eds.), Handbook of Research on e-Transformation and Human Resources Management Technologies: Organizational Outcomes and Challenges. New York: Hershey. http://dx.doi.org/10.4018/978-1-60566-304-3.ch003

Joseph, R., \& Kitlan, D. (2006). Key issues in government and public administration. In G. D. Garson \& M. Khosrow-Pour (Eds.), Handbook of research on public information technology. Hershey, P.A: IGI Global.

Judd, C. M., \& Kenny, D. A. (1981). Process Analysis: Estimating mediation in treatment evaluations. Evaluation Review, 5(5), 602-619. http://dx.doi.org/10.1177/0193841X8100500502

Keegan, A., \& Francis, H. (2008). HRM, technology and strategic roles: considering the social implications. In G. Martin, M. Reddington \& H. Alexander (Eds.), Technology, Outsourcing and Transforming HR. Amsterdam: Elsevier. http://dx.doi.org/10.1016/B978-0-7506-8645-7.50021-0

Kenny, D. A. (2012, April 3). Mediation. Retrieved June 9, 2012, from http://www.ehow.com/mediation

Lawler, E., \& Mohrman, S. (2003). HR as a strategic partner: What does it take to make it happen? Human Resource Planning, 26(3), 15-29.

Lawler, E., Levenson, A., \& Boudreau, J. (2004). HR metrics and analytics: use and impact. Human Resource Planning, 27(4), 27-35.

Legnick-Hall, M., \& Moritz, S. ( 2003). The Impact of e-HR on the Human Resource Management Function. Journal of Labour Research, 24(3), 365-379. http://dx.doi.org/10.1007/s12122-003-1001-6

Lepak, D., \& Snell, S. (1998). Virtual HR: Strategic Human Resource Management in the 21st Century. Human Resource Management Review, 8(3), 215-234. http://dx.doi.org/10.1016/S1053-4822(98)90003-1

Lepak, D., Bartol, K. M., \& Erhardt, N. L. (2005). A contingency framework for the delivery of HR practices. Human Resource Management Review, 15(2), 139-159. http://dx.doi.org/10.1016/j.hrmr.2005.06.001

Lepak, D., Smith, K., \& Taylor, M. (2007).Value creation and value capture: a multilevel perspective. Academy of Management Review, 32, 180-194. http://dx.doi.org/10.5465/AMR.2007.23464011

Logan, J. K. (2000). Retention tangibles and intangibles: More meaning in work is essential, but good chair massages won't hurt. Training \& Development, 54(4), 48-50.

Loijen, Y. (2011). E-HRM and value creation: Does organizational context make a difference? Utrecht, Netherlands: University of Twente.

Maatman, M. (2006). Measuring the effectiveness of E-HRM:The development of an analytical framework for the measurement of E-HRM and its application within a Dutch Ministry. Twente: The Dutch Ministry of Interior Affairs.

Malhotra, Y. (2005). Integrating knowledge management technologies in organizational business processes: getting real time enterprises to deliver real business performance. Journal of Knowledge Management, 9(1), 


\section{7-28. http://dx.doi.org/10.1108/13673270510582938}

Marler, J. (2009). Making Human Resources strategic by going to the Net: reality or myth? The international Journal of Human Resource Management, 20(3), 515-527. http://dx.doi.org/10.1080/09585190802707276

Martin, G., Reddington, M., \& Alexander, H. (2008). Technology, Outsourcing and Transforming HR. Oxford: Butterworth-Heinemann.

Martinsons, M. (1994). Benchmarking human resource information systems in Canada and Hong Kong. Information \& Management, 26(6), 305-316. http://dx.doi.org/10.1016/0378-7206(94)90028-0

Moses, B. (2000). Give people belief in the future: In these cynical times, HR must assure employees that faith and work can coexist. Workforce, 79(6), 134-139.

Ngai, E., \& Wat, F. (2006). Human resource information systems: a review and empirical analysis. Personnel Review, 35, 297-314. http://dx.doi.org/10.1108/00483480610656702

Noe, R. A., Hollenbeck, J. R., Gerhart, B., \& Wright, P. M. (2008). Human Resource Management: Gaining a Competive Advantage (6th ed.). New York: McGraw-Hill Companies, Inc.

Panayotopoulou, L., Vakola, M., \& Galanaki, E. (2007). E-Hr Adoption and the Role of HRM: Evidence from Greece. Personnel Review, 36(2), 277-294. http://dx.doi.org/10.1108/00483480710726145

Parry, E., Tyson, S., Selbie, D., \& Leighton, R. (2007). HR and Technology: Impact and Advantages. London: Charted Institute of Personnel and Development.

Pawlowski, J. M., \& Richter, T. (2010). A methodology to compare and adapt e-learning in the global context. In M. H. Breitner et al. (Eds.), E-Learning 2010. Berlin Heidelberg: Physica-Verlag. http://dx.doi.org/10.1007/978-3-7908-2355-4_1

Porter, M. (1985). Competitive Advantage: Creating and Sustaining Superior Performance. New York, NY.: The Free Press.

Roehling et al. (2005). The future of HR management: Research needs and directions. Human Resource Management, 44(2), 207-212. http://dx.doi.org/10.1002/hrm.20066

Ruël, H., Bondarouk, T., \& Velde, M. V. (2007). The contribution of E-HRM to HRM effectiveness: Results from a quantitative study in a Dutch Ministry. Employee relations, 29(3), 280-291. http://dx.doi.org/10.1108/01425450710741757

Ruta, C. (2005). The application of change management theory to HR portal implementation in subsidiaries of multinational corporations. Human Resource Management, 44(1), 35-53. http://dx.doi.org/10.1002/hrm.20039

Sareen, P. (2012). E-HRM: A Strategic Review. International Journal of Human Resource Studies, $2,3$. http://dx.doi.org/10.5296/ijhrs.v2i3.2100

Schramm, J. (2009, June 8). HR technology competencies: New roles for HR professionals. Retrieved Decdember 11, 2011, from http://www.findarticles.com/p/articles/mi_m3495/is_4_51/ai_n26840916/

Shrivastava, S., \& Shaw, J. (2004). Liberating HR through technology. Human Resource Management, 42, 201-222. http://dx.doi.org/10.1002/hrm.10081

Stanton, M., \& Coovert, M. (2004). Turbulent waters: The intersection of information technology and human resources. Human Resource Management, 43(2), 121-125. http://dx.doi.org/10.1002/hrm.20010

Stauss, B., Chojnacki, K., Decker, A., \& Hoffman, F. (2001). Retention effects of a customer club. International Journal of Service Industry Management, 12(1), 7-19. http://dx.doi.org/10.1108/09564230110382745

Steel, R. P., Griffeth, R. W., \& Hom, P. W. (2002). Practical retention policy for the practical manager. Academy of Management Executive, 16, 149-162. http://dx.doi.org/10.5465/AME.2002.7173588

Stone, D. (2009). The brave new world of e-HR: Human resources management in the digital age. San Francisco: Jossey Bass.

Strohmeier, S. (2009). Concepts of E-HRM consequences: A categorisation, review and suggestion. The International Journal of Human Resource Management, 20, 528-543. http://dx.doi.org/10.1080/09585190802707292 
Strohmeier, S., \& Kabst, R. (2009). Organizational Adoption of E-HRM in Europe: An Empirical Explanation of Major Adoption Factors. Journal of Managerial Psychology, 24(6), 482. http://dx.doi.org/10.1108/02683940910974099

Sun, J., \& Cahan, S. (2012). The economic determinants of compensation committee quality. Managerial Finance, 38(2), 188-205. http://dx.doi.org/10.1108/03074351211193721

Tan, M., \& Teo, T. (2000). Factors influencing the adoption of Internet banking. Journal of the Association for Information Systems, 1, 1-42.

Townsend, A., \& Bennett, J. (2003). Human resources and information technology. Journal of Labor Research, 24(3), 361-363. http://dx.doi.org/10.1007/s12122-003-1000-7

Venkatesh, V. (2000). Determinants of perceived ease of use: integrating control, intrinsic Motivation, and Emotion into the Technology Acceptance Model. Info. Syst. Res., 11(4), $342-365$. http://dx.doi.org/10.1287/isre.11.4.342.11872

Verheijen, L., \& Dewulf, L. (2004). Vormgeven aan leren als een relationeel process "Shaping learning as a relational process". Opleiding and Ontwikkeling, 11, 25-28.

Viswesvaran, C. (2003). Introduction to special issue: Role of technology in shaping the future of staffing and assessment. International Journal of Selection and Assessment, 11(2/3), 107-112. http://dx.doi.org/10.1111/1468-2389.00233

Voerman, M., \& Veldhoven, M. V. (2007). Attitude towards E-HRM: An Empirical Study at Philips. Personnel Review, 36(6), 887-902. http://dx.doi.org/10.1108/00483480710822418

Walker, J. W. (2001). Zero defections? Human Resource Planning, 24(1), 6-8.

Zineldin, M. (2000). TRM Total Relationship Management. Student litterateur, Lund.

\section{Copyrights}

Copyright for this article is retained by the author(s), with first publication rights granted to the journal.

This is an open-access article distributed under the terms and conditions of the Creative Commons Attribution license (http://creativecommons.org/licenses/by/3.0/). 